\author{
M.I. Coф'ï \\ кандидат юридичних наук, \\ докторант \\ Науково-дослідного інституту публічного права
}

\title{
ДО ХАРАКТЕРИСТИКИ ФОРМ І МЕТОДІВ ЗДІЙСНЕННЯ ФІСКАЛЬНОЇ ПОЛІТИКИ В УКРАЇНІ
}

Постановка проблеми. 3 моменту проголошення незалежності влада намагається виробити оптимальну державну політику у сфері оподаткування, і в деяких важливих аспектах в останні роки досягла успіхів. Однак поки що зарано говорити про те, що в Україні сформовано та реалізується ефективна та дієва фіскальна політика, яка повною мірою відповідає потребам суспільно-економічного розвитку нашої держави, а також європейським стандартам. А тому зазначена сфера потребує уваги з боку вітчизняних науковців. Варто зазначити, що кожна суспільна діяльність має свої форми, i фіскальна політика у цьому не є виключенням. Як система заходів, мір, що становлять зміст цієї політики, вона також здійснюється через певні форми, дослідження яких дозволить з'ясувати те, у якому вигляді, яким чином означена політика виражається, реалізується у практичній діяльності відповідних органів публічного управління.

Стан дослідження. Загальнотеоретичним аспектам здійснення фіскальної політики в Україні присвячували свою увагу: М. Кучерявенко, Ф. Ярошенко, В. Андрущенко, Т. Меркулова, М. Гридчина, Д. Кобильнік, О. Бородін, Г. Бех, В. Тропина, Н. Вдовиченко В. Білоцерківець, Я. Жаліло, О. Дмитрик, В. Попова, А. Крисоватий, С. Маслюченко, Я. Литвиненко, А. Калина та ін. Однак, незважаючи на чималу кількість наукових розробок, питання форм і методів здійснення фіскальної політики в Україні практично залишилось поза увагою науковців.

Саме тому мета статті - визначити та надати характеристику формам i методам здійснення фіскальної політики в Україні.

Виклад основного матеріалу. Аналіз наукової літератури дає змогу стверджувати, що форми здійснення фіскальної політики слід розуміти як зовнішнє вираження, спосіб виявлення в об'єктивній дійсності дій компетентних суб'єктів публічної влади, що становлять зміст цієї політики. Дослідження форм фіскальної політики дозволяє біль чітко та глибокого усвідомити ї̈ сутнісний зміст, зрозуміти яким чином організовано цю політику та відбувається її впровадження у практичне життя. До основних форм здійснення фіскальної політики, на нашу думку, слід віднести такі, як:

1) нормотворча діяльність. Нормотворчість, пише О.Ф. Скакун, - це офіційна діяльність уповноважених суб'єктів держави та громадянського суспільства щодо встановлення, зміни, призупинення і скасування правових норм, їх систематизації [1, с. 342]. Головне призначення нормотворчості, продовжує науковець, - це формулювання нових правових норм, котрі притаманні соціальним відносинам, тобто моделювання суспільних відносин, які з позицій держави або громадянського суспільства (народу) є припустимими (бажаними) чи необхідними (обов'язковими). Зміна чинних і скасування застарілих правових норм сприяють утвердженню нових норм i, отже, вони входять до складу нормотворчості як його допоміжні вияви [1, с. 342]. Звідси - значення нормотворчості як форми здійснення фіскальної політики полягає у тому, що саме через застосування першої встановлюються юридичні матеріальні та процедурні правила формування та реалізації зазначеної політики, закріплюються ключові принципи, пріоритети та гарантії її проведення. Слід відмітити, що на особливому значення законодавчого врегулювання фіскальної політики, зокрема в тій її частині, що стосується оподаткування, наголошували європейські дослідник ще у XVIIXVIII ст. [2, с. 21-23]. Сама нормотворчість проявляється у вигляді законодавчої та підзаконної діяльності. У ході першої приймаються закони, які регулюють найбільш важливі аспекти фіскальної політики, зокрема такі як: структура податкової системи, податкові ставки, порядок справляння податків, порядок формування бюджету та здійснення видатків із нього, правовий статус суб'єктів фіскальних правовідносин тощо. Одними з ключових законів із питань фіскальної політики України є Податковий і Бюджетний кодекси України. У свою чергу підзаконна нормотворчість покликана розвивати, конкретизувати та уточнювати загальні законодавчі положення, пристосовувати їх до специфіки тих чи інших ситуації у фіскальній сфері. Най частіше підзаконна нормотворчість стосується саме порядку реалізації, втілення законодавчих положень;

2) адміністрування. Адміністрування за своєю суттю - це управлінська діяльність посадових осіб, що має чітко регламентовані функції; уміння практично організувати виконавчо-розпорядчу та виробничу діяльність; стиль управління, за якого діяльність фокусується на процедурах і контролі правильного виконання розпоряджень. У широкому значенні, зазначає І.Г. Сурай, 
адміністрування - це не тільки професійна діяльність чиновників, а й уся система адміністративних інститутів з достатньо суворою ієрархією, за допомогою якої відповідальність за виконання державних рішень «спускається» зверху вниз. У цьому випадку поняття адміністрування відповідає поняттю адміністративного державного управління, яке визначає особливу соціальну функцію, спрямовану на упорядкування розвитку в інтересах всього суспільства, де державний чиновник виступає соціальним агентом влади. У вузькому розумінні адміністрування означає професійну діяльність державних чиновників, спрямовану на виконання рішень керівництва [3]. Тож значення адміністрування як форми здійснення фіскальної політики обумовлене тим, що саме в межах цієї форми відбувається реалізація, практичне втілення тих принципів, правил, заходів, що закріплені у відповідному законодавстві. Одним із основних та найважливіших елементів адміністрування $є$ контроль, якому належить особлива роль як засобу забезпечення законності у сфері фіскальних відносин. Контроль, зазначає В.Б. Авер'янов, орієнтований на забезпечення злагодженої, чіткої роботи органів державної влади усіх рівнів і ланок, сумлінне і якісне виконання, раціональне використання їі посадовими особами та державними службовцями, усім складом працівників наданих їм прав та відповідальне ставлення до виконання своїх обов'язків у відносинах з громадянами. Змістом контролю, є спостереження та перевірка розвитку суспільної системи й усіх їі елементів відповідно до визначених напрямів, а також попередження та виправлення можливих помилок і неправомірних дій, що перешкоджають такому розвитку [4, с. 349]. Контроль, як пише С.В. Ківалов, $€$ важливою ознакою змісту державного управління, він являє собою спостереження за відповідністю діяльності керованого об'єкта приписам, отриманим від керівного суб’єкта, та виконанням прийнятих рішень. Функція контролю у державному управлінні полягає в аналізі та зіставленні фактичного стану тієї чи іншої галузі з вимогами, які стоять перед нею, відхилень у виконанні поставлених завдань і причин таких відхилень, а також в оцінці діяльності й доцільності саме такого шляху [5, с. 291]. Тож контроль, як один із ключових елементів адміністрування, спрямований на підтримку режиму законності у сфері фіскальних відносин, він покликаний забезпечувати суворе та неухильне дотримання учасниками таких відносин відповідних матеріальних і процедурних правил поведінки. Крім того, контроль є одним із основних джерел, через яке компетентні суб'єкти, що здійснюють фіскальну політику, отримують інформацію про наявні прогалини, недоліки та інші проблеми у зазначеній політиці. Завдяки цьому влада має змогу вчасно й оперативно реагу- вати на ті чи інші проблеми у фіскальній політиці. Основною формою контролю у межах фіскальної політики є податковий контроль - система заходів, що вживаються контролюючими органами та координуються центральним органом виконавчої влади, що забезпечує формування та реалізує державну фінансову політику, з метою контролю правильності нарахування, повноти і своєчасності сплати податків і зборів, а також дотримання законодавства з питань регулювання обігу готівки, проведення розрахункових та касових операцій, патентування, ліцензування та іншого законодавства, контроль за дотриманням якого покладено на контролюючі органи [6];

3) взаємодія. На сторінках словникової, наукової та навчальної літератури наводиться багато визначень поняття «взаємодія», як у загальному розумінні, так і у контексті якої конкретної сфери наукової чи практичної діяльності. Так, наприклад, М.М. Бурбика тлумачить взаємодію як засновану на об'єктивно існуючих між державними органами взаємних зв' язках, ініціативі та зацікавленості сторін узгоджена діяльність, що здійснюється у формі співробітництва, взаємної допомоги та підтримки за відсутності єдиного керівництва, у процесі якої забезпечується раціональне та комплексне вирішення загальних завдань щодо зміцнення законності [7]. В.П. Сапальов пропонує розглядати взаємодію як спільно організовану внутрішню та зовнішню діяльність, яка грунтується на чинному законодавстві, узгоджена за метою, місцем і часом, умовами здійснення якої є чіткий розподіл обов'язків, узгодженість дій і централізоване керівництво [8, с. 27]. Отже, незважаючи на різноманіття визначень взаємодії, iï сутнісні ознаки, залишаються незмінними це об'єднання зусиль суб'єктів задля досягнення спільних цілей і надання допомоги один одному у реалізації власних завдань. Особливе значення взаємодії як форми реалізації фіскальної полягає у тому, що вона:

- по-перше, забезпечує необхідні рівень i якість комунікації між суб’єктам здійснення фіскальної політики та тими, щодо яких заходи цієї політики здійснюються, що надзвичайно важливо в умовах розвитку в державі концепції партнерських відносин контролюючих органів і платників податків;

- по-друге, є важливою умовою забезпечення належної якості та ефективності громадського контролю у фіскальній сфері;

- по-третє, дозволяє залучати значні ресурси для реалізації найбільш складних і принципових заходів;

4) інформаційно-освітня діяльність, завдяки якій забезпечується:

- по-перше, необхідний рівень поінформованості громадськості про ключові засади та зміст 
фіскальної політики в державі, її стан та перспективи подальшого розвитку;

- по-друге, підвищується рівень правової грамотності населення в частині обізнаності громадян про їх прав і обов'язки у фіскальній сфері;

- по-третє, належний рівень правової свідомості та правової культури платників податків, що $€$ важливою умовою забезпечення добровільного виконання ними своїх обов'язків у фіскальних відносинах, учасниками яких вони $є$.

Поряд із формами здійснення фіскальної політики важлива роль належить їі методам, які являють собою сукупність способів, прийомів за допомогою яких суб'єкти такої політики реалізують заходи і міри, що становлять їі зміст. Залежно від характеру та змісту можна виокремити багато різновидів методів: економічні, фінансові, організаційні, правові, освітньо-виховні та ін. Враховуючи те, що у цьому досліджені фіскальну політику ми розглядаємо у адміністративно-правовому контексті, то особливі інтерес для нас становлять такі правові методи їі здійснення як переконання і примус. Переконання- це спосіб впливу на свідомість і поведінку людей з використанням роз'яснювальних і виховних заходів iз метою дотримання вимог чинного законодавства [9, с. 173]. Воно (тобто переконання), зазначають В.I. Кунченко-Харченко та В.Г. Печерський, формує правосвідомість, внутрішню психічну готовність об'єкта управління до виконання керівної вказівки та пов'язане із використанням різних організаційних, роз'яснювальних і виховних заходів [10, с. 392]. В умовах розвитку у податковий сфері концепції партнерських відносин між органами влади та платниками податків, переконання як метод проведення державної фіскальної політики набуває особливого значення. Оскільки цей метод має яскраво виражену гуманістичну сутність, він не передбачає прямого тиску на особо, їі примушування до виконання чогось під загрозою можливості застосування до неї покарання. Натомість зміст цього методу становлять такі способи впливу як роз'яснення, виховання, інформування, пропаганда, що орієнтовані на: спонукання суб'єктів до правомірної поведінки у сфері фіскальних відносин; формування у їх свідомості позитивних настанов, переконань у доцільності і вірності саме такої форми поведінки. 3 цього приводу слушно зазначає С.О. Сергєєв, котрий, аналізуючи фіскальні відносини та методи організації, пише, що переконання як метод впливу на волю й свідомість людини - доволі складний процес, у якому знаходять свій вияв соціальні, психологічні, моральні та інші аспекти. Держава, використовуючи переконання, домагається того, щоб люди усвідомили необхідність правомірної поведінки. Одночасно переконання включає і складний механізм емоційного впливу з тим, щоб ідеї, погляди, принципи були підкріплені відповідними емоціями й почуттями людей. Лише в такому разі воля держави, колективу стає нібито власною волею особи, щодо якої застосовується переконання, з'являється внутрішня потреба додержання норм моралі і права. Таким чином, сутність переконання полягає в тому, що переконуючий (державні органи, колектив, окрема людина) впливає на переконуваного з метою вироблення в нього стійких внутрішніх стимулів на користь тих відносин між людьми, які закріплені в нормах права, моралі, інших соціальних нормах [11, с. 127-128].

Що стосується примусу, то це метод впливу держави на особу та суспільство, з метою забезпечення належної реалізації норм права, котрий здійснюється через правозастосовну діяльність незалежно від волі та бажання юридично зобов'язаних суб'єктів [12, с. 91]. Примус, наголошує В.Я. Малиновський, являє собою метод управління, що заснований на авторитеті держави і силі закону, спрямований на суб'єкт і об'єкт управління, з метою досягнення встановлених параметрів діяльності, вироблення певних форм поведінки та підтримання суспільної дисципліни [13, с.406]. Отже, на відміну від переконання, примус метод проведення політики, який передбачає застосування до суб'єктів фіскальних відносин відповідних заходів і мір незалежно від їх волі, бажання. Цей метод використовується у тих випадках, коли переконання на призвело до настання бажаних наслідків і суб'єкти, щодо яких реалізується фіскальна політика, не бажають добровільно належними чином виконувати покладені на них законом обов'язки. У такому випадку компетентні контролюючі органи, посадові особи, у цілях захисту суспільних і державних інтересів, застосовують до таких суб'єктів, на підставі, порядку та межах визначених законом, відповідні заходи тиску. Примус виступає важливим засобом відновлення порушеного правопорядку, усунення умов і факторів, що сприяли чи можуть посприяти такому порушенню.

Висновок. Отже, форми та методи є обов'язковими та дуже важливими елементами організаційно-правового механізму здійснення фіскальної політики в Україні. Кожен із них виконує свою роль у цьому механізмі, так, якщо форми виражають способи зовнішнього вираження, існування такої політики у об'єктивній дійсності, то методи характеризують те, яким чим, у який спосіб заходи цієї політики реалізуються у суспільному житті, застосовуються що о відповідних суб'єктів. Вивчення проблемних аспектів форм i методів фіскальної політики дозволяє з'ясувати наявні прогалини, недоліки, прорахунки у структурі цієї політики та способах її проведення у практичне життя. 


\section{Jimepamypa}

1. Скакун О.Ф. Теорія права і держави : підручник. Київ : Алерта ; ЦУЛ, 2011. 520 с.

2. Берендтс. Э.Н. Русское финансовое право. Санкт-Петербург, 1914.453c.URL:http://library6.com/ books/720086.pdf.

3. Сурай І.Г. Адміністрування. Велика украӥнська енииклопедія. URL: https://vue.gov.ua/\% D0\% 90\% D 0 $\%$ B $4 \%$ D0 $\%$ BC $\%$ D1 $\% 96 \%$ D0 $\%$ BD $\%$ D1 $\% 96 \%$ D $1 \% 8$ $1 \%$ D1 $\% 82 \%$ D1 $\% 80 \%$ D1 $\% 83 \%$ D0 $\%$ B2 $\%$ D0 $\%$ B0 $\%$ D0 $\% \mathrm{BD} \% \mathrm{D} 0 \% \mathrm{BD} \% \mathrm{D} 1 \% 8 \mathrm{~F}$.

4. Адміністративне право України. Академічний курс : підручник : у 2 т. Т. 1. Загальна частина / ред. кол.: В.Б. Авер'янов. Київ : Видавництво «Юридична думка», 2004. 584 с.

5. Административное право Украины : учебник / под общ. ред. С.В. Кивалова. Харьков : «Одиссей», $2004.880 \mathrm{c}$

6. Податковий кодекс України від 02 грудня 2010 p. № 2755-VI. URL: https://zakon.rada.gov.ua/ laws/show/2755-17.

7. Бурбика М.M. Міжнародний досвід адміністративно-правового забезпечення взаємодії правоохоронних органів. Наука і правоохорона. 2013. № 2 (20). C. 21-25.

8. Сапальов В.П. Теоретичні аспекти взаємодії підрозділів кримінального пошуку при використанні оперативно-технічних засобів. Вісник Луганського інсти туту внутрішніх справ МВС України імені 10-річчя незалежності Украӥни. Спец. вип. 2001. № 2. С. 17-28.

9. Стеценко С.Г. Адміністративне право України : навчальний посібник. Київ : Атіка, 2007. 624 с.

10. Кунченко-Харченко B.I., Печерський В.Г., Трубін Ю.Ю. Правознавство : навчальний посібник. Київ : Кондор, 2011. 474 с.

11. Правове регулювання фіскальних правовідносин в Україні : дис. ... канд. юрид. наук : 12.00.07 Харківський національний ун-т внутрішніх справ. Харків, 2007. 185 с.

12. Калєніченко Л.І. Державно-правовий примус та система його форм. Правоохоронна функиіл держа ви: теоретико-методологічні та історико-правові проблели : тези доп. круглого столу (м. Харків, 27 жовтня 2017 р.) / МВС України, Харків. нац.. ун-т внутр. справ. Харків, 2017. С. 89-92.

13. Малиновський В.Я. Державне управління : навчальний посібник. Київ : Атіка, 2003. 576 с.

\section{Анотація}

Соф’̈̈н М. I. До характеристики форм і методів здійснення фіскальної політики в Україні. - Стаття.

У статті на основі аналізу наукових поглядів вчених і норм чинного законодавства України визначено та надано характеристику формам і методам здійснення фіскальної політики в Україні. Обгрунтовано, що форми і методи виконують особливу роль у механізмі здійснення фіскальної політики в Україні. Зокрема, якщо форми виражають способи зовнішнього вираження, існування цієї політики в об'єктивній дійсності, то методи характеризують те, у який спосіб заходи такої політики реалізуються у суспільному житті, застосовуються щодо відповідних суб'єктів. Наголошено, що основною формою контролю у межах фіскальної політики є податковий контроль - система заходів, що вживаються контролюючими органами та координуються центральним органом виконавчої влади, що забезпечуе формування та реалізує державну фінансову політику, з метою контролю правильності нарахування, повноти і своєчасності сплати податків і зборів, а також дотри- мання законодавства 3 питань регулювання обігу готівки, проведення розрахункових і касових операцій, патентування, ліцензування та іншого законодавства, контроль за дотриманням якого покладено на контролюючі органи. 3'ясовано, що, на відміну від переконання, примус метод проведення політики, який передбачає застосування до суб'єктів фіскальних відносин відповідних заходів і мір незалежно від їх волі, бажання. Цей метод використовується у тих випадках, коли переконання на призвело до настання бажаних наслідків і суб'єкти, щодо яких реалізується фіскальна політика, не бажають добровільно належними чином виконувати покладені на них законом обов'язки. У такому разі компетентні контролюючі органи, посадові особи, у цілях захисту суспільних та державних інтересів, застосовують до таких суб'єктів, на підставі, порядку та межах визначених законом, відповідні заходи тиску. Примус виступає важливим засобом відновлення порушеного правопорядку, усунення умов і факторів, що сприяли чи можуть посприяти такому порушенню. Зроблено висновок, що форми і методи є обов'язковими та дуже важливими елементами організаційно-правового механізму здійснення фіскальної політики в Україні. Кожен із них виконує свою роль у цьому механізмі, так, якщо форми виражають способи зовнішнього вираження, існування цієї політики у об'єктивній дійсності, то методи характеризують те, яким чим, у який спосіб заходи цієї політики реалізуються у суспільному житті, застосовуються щодо відповідних суб'єктів. Вивчення проблемних аспектів форм і методів фіскальної політики дозволяє з'ясувати наявні прогалини, недоліки, прорахунки у структурі цієї політики та способах їі проведення у практичне життя.

Ключові слова: фіскальна політика, форми, методи, нормотворчість, адміністрування, примус, переконання.

\section{Summary}

Sofin M. I. To the characteristics of the forms and methods of public policy in Ukraine. - Article.

In the article, based on the analysis of scientific views of scientists and the norms of the current legislation of Ukraine, the characteristics and forms of implementation of fiscal policy in Ukraine are described and given. It is substantiated that forms and methods play a special role in the mechanism of implementation of fiscal policy in Ukraine. In particular, if the forms express the ways of external expression, the existence of this policy in objective reality, then the methods characterize the way in which the measures of this policy are implemented in public life, apply to the relevant entities. It was emphasized that the main form of control within fiscal policy is tax control - a system of measures taken by supervisory bodies and coordinated by the central executive body, which ensures the formation and implementation of the state financial policy, in order to control the correctness of accrual, completeness and timely payment of taxes and fees, as well as compliance with the legislation on cash management, settlement and cash operations, patenting, licensing and other legislation, control over receipt of which is entrusted to supervisory authorities. It is found that, in contrast to persuasion, the coercive method of policy implementation, which involves the application of appropriate measures and measures to subjects of fiscal relations, regardless of their will, desire. This method is used in cases where the belief has led to the desired effects and the subjects in relation to which the fiscal policy is being implemented are not willing to voluntarily perform their statutory duties in a proper manner. In this case, the competent control authorities, officials, in order to 
protect public and state interests, apply appropriate pressure measures to such entities, on the basis, in the order and within the limits specified by law. Compulsion acts as an important means of restoring violated law and order, eliminating the conditions and factors that contributed or may contribute to such a violation. It is concluded that the forms and methods are obligatory and very important elements of the organizational and legal mechanism for the implementation of fiscal policy in Ukraine. Each of them performs its role in this mechanism, so if the forms express the ways of external expression, the existence of this policy in objective reality, then the methods characterize the way how, in what way the measures of this policy are implemented in public life, apply in relation to the relevant entities. The study of the problematic aspects of fiscal policy forms and methods allows us to find out the gaps, shortcomings, miscalculations in the structure of this policy and how it is conducted in practical life.

Key words: fiscal policy, forms, methods, norm-making, administration, coercion, persuasion. 